\title{
Antitrust Merger Investigations
}

\author{
And \\ The Quality Of Reported Earnings \\ Stephen D. Makar, (E-mail: makar@uwosh.edu), University of Wisconsin - Oshkosh \\ Pervaiz Alam, (E-mail: palam@kentvm.kent.edu), Kent State University \\ Michael A. Pearson, (E-mail: mpearson@kentvm.kent.edu), Kent State University
}

\begin{abstract}
Antitrust merger policy under Section 7 of the Clayton Act prohibits acquisitions that substantially lessen competition or tend to create a monopoly. Previous studies, however, indicate that government regulators have not been effective in identifying anticompetitive behavior. This paper examines whether accounting information used in assessing the competitive impact of mergers is subject to manipulation by investigated firms. We examine both total accruals and current accruals for manipulation and consider the implications of such earnings management for the quality of reported earnings. The results indicate that firms investigated for Section 7 violations during the 1974-1992 period do indeed manage reported earnings to influence regulatory efforts in discerning excess profits and anticompetitive behavior.
\end{abstract}

\section{Introduction}

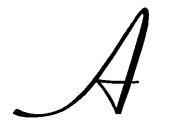

ntitrust merger policy in the U.S. seeks to discern anticompetitive acquisitions. Under Section 7 of the Clayton Act, the Antitrust Division of the Department of Justice (DOJ) and the Federal Trade Commission (FTC) identify and prohibit acquisitions that substantially lessen competition or tend to create a monopoly.

Antitrust regulators, however, have been criticized as being too lenient in their investigations (see, e.g., Novak, Clark and Yoder, 1995). The merger wave of the 1990s, in particular, has led to public fears that American business is "plunging headlong toward huge new

Readers with comments or questions are encouraged to contact the authors via e-mail. concentrations of economic power" (Murray, 1996, p. A1). According to Eckbo (1992), prior studies indicate that antitrust regulators have not been effective in identifying anticompetitive mergers. Indicative of public concern, observers are asking: "What happened to antitrust?" (Lowenstein, 1997, p. A1).

In this study, we consider whether accounting information used in antitrust merger investigations is subject to manipulation by investigated firms. To the extent that investigated firms manage their reported earnings, earnings quality declines and regulatory efforts are likely to be obstructed. Evidence of such earnings management should interest accounting and antitrust regulators as well as others concerned with the quality of reported earnings. 
Recent research has shown that firms have incentive to reduce reported earnings in order to influence regulatory efforts. Such earnings management incentives pertain to government imposed wealth transfers or political costs. ${ }^{i}$ For instance, Jones (1991) found that firms seeking import relief from the International Trade Commission manage their reported earnings to increase the likelihood and/or amount of such relief. Similarly, Cahan (1992) demonstrated that monopolies use accounting manipulations to affect regulatory investigations. Our study differs from prior studies on two important dimensions: (1) we focus our analysis on the context of antitrust merger investigations, and (2) we frame such analysis in relation to the quality of reported earnings.

\section{Quality of Reported Earnings}

As part of its conceptual framework, the Financial Accounting Standards Board (FASB) has described the objectives of financial reporting and has enumerated the qualitative characteristics of accounting information. In Statement of Accounting Concepts No. 1, the FASB calls for financial reporting "to provide information that is useful in making business and economic decisions" (Financial Accounting Standards Board, 1978, par. 9), where the primary characteristics are relevance and reliability (Financial Accounting Standards Board, 1980). Ideally, generally accepted accounting principles (GAAP) would ensure the reporting of relevant and reliable information, subject to cost/benefit and materiality considerations. In short, earnings quality can be described as the closeness of reported earnings to economic reality.

Unfortunately, GAAP are less than ideal, and reported earnings may fall short of capturing economic reality (i.e., true earnings). For example, the convention of conservatism introduces bias into accounting measurement and valuation techniques. Techniques such as the lower of cost or market rule result in understated net assets and earnings. Moreover, firms have discretion over business activities and accounting practices, where such discretion may occur within or outside of the bounds of GAAP. Specifically, reported earnings can be manipulated via the timing of business activities, the selection of accounting methods to report such activities, and the timing of the accounting recognition (Makar, Alam and Pearson, 1996).

Prior evidence of reported earnings quality is limited, in part due to such earnings management efforts as well as to the conservatism bias (Lev, 1989). Some users see managed earnings for what they are. For example, the discretionary sources of Citibank's fourth quarter 1997 income led one bank analyst to label her performance report "To Heck with Quality Earnings" (Frank and Browning, 1998). In contrast, other users mistakenly equate the quality of managed earnings with the direction of the managing. Reported earnings are labeled "high quality" if they were managed downward and "low quality" if managed upward. While managing earnings downward is conservative, it clearly is not reliable and often leads to overstated earnings (i.e., not conservatism) being reported in later periods (Ip, 1996). In this study, we consider whether income decreasing manipulations are made by firms under investigation for antitrust merger violations. To the extent that investigated firms manage their reported earnings downward, such information departs from economic reality, and the quality of reported earnings declines. In this way, we respond to calls for research on the implications of earnings management for the quality of accounting information (see Easterwood, 1998). By examining the manipulation of accruals in particular, this study addresses what Schipper (1989) has described as "one of the central questions confronted by practicing professional accountants and academic accountants ... the influence and importance of accounting accruals" (p. 91).

\section{Antitrust Merger Investigations}

Antitrust merger policy in the U.S. is 
rooted in the Sherman Act, which was passed in 1890. The Sherman Act broadly prohibits behavior that is considered to be anticompetitive. Although often criticized for its lack of specificity, this statute was intentionally drafted to be adaptable to changing political, social and economic conditions (Waters, 1989). The Sherman Act was reinforced by the Clayton Act in 1914. The Clayton Act's Section 7 prohibits mergers if "the effect of such acquisition may be substantially to lessen competition or tend to create a monopoly." In enforcing antitrust law, the DOJ is largely responsible for upholding the Sherman Act, and shares Clayton Act jurisdiction with the FTC (Waldman, 1986).

We argue that firms negotiating mergers in oligopolistic markets have incentives to manage their reported earnings to influence DOJ and FTC investigations. Antitrust regulators use reported earnings in discerning the competitive impact of a merger (Elzinga, 1989; Baker and Bresnahan, 1992). ${ }^{2}$ While the use of profits in assessing $_{\star}$ a merger's competitive effect is imperfect, antitrust regulators endure such imprecision given their objective of prohibiting either the creation of monopolies or the reinforcement of anticompetitive oligopolies that promote tacit price coordination (Areeda, 1988). According to Eisner and Meier (1990), for example, firms in concentrated industries may form and maintain collusive pricing, output, and/or promotional policies that result in supracompetitive profits. ${ }^{3}$ Thus, investigated merging firms have considerable interest in managing reported earnings to avoid the appearance of excess profits and anticompetitive behavior.

For example, investigated firms can decrease reported earnings by increasing the amount of reserves for estimated inventory obsolescence. In accounting, the recognition of these and other estimated expenses in advance of cash outlays is termed "accruals." Accrualbased earnings are considered to be a more useful measure of corporate performance because the expense is recorded in the period of benefit, rather than in the period of actual cash outlay. Generally accepted accounting principles provide guidance in estimating accruals to enhance the quality of reported earnings, but within that guidance there is ample room for discretion.

\section{Earnings Management Expectations}

We assume that investigated firms prefer accrual manipulations to accounting method changes in avoiding the appearance of excess profits. Like Cahan (1992), we argue that tests of accounting method changes are inappropriate in antitrust contexts, as such changes are fully disclosed in the financial statements. In contrast, accrual manipulations hold greater promise of affecting regulatory efforts, as these manipulations are subtle and less obvious to financial statement users. We also argue that accrual and earnings management efforts designed to reduce regulatory interference with mergers are not entirely inconsistent with shareholder interests. Rather, like Jones (1991), we assume that shareholders are likely to tolerate income-decreasing accruals in the current period to the extent that future earnings benefit from such reduced antitrust interference.

Firms investigated for Section 7 antitrust merger violations have incentives to manage reported earnings to influence regulatory efforts in discerning excess profits and anticompetitive behavior. Thus, we expect investigated firms to reduce the quality of reported earnings through income-decreasing accruals in the periods surrounding their Section 7 investigations. In contrast to these experimental sample firms, the manipulative or discretionary accruals of our noninvestigated control firms are likely to be statistically insignificant. Accordingly, the alternative hypothesis is:

Ha. Investigated firms' discretionary accruals are significantly income decreasing in periods surrounding the investigation. 


\section{Sample, Data, and Results}

Sample and Data

Our population is Compustat firms investigated for Section 7 antitrust merger violations over the 1974-1992 period. These firms were identified from Commerce Clearing House's Trade Cases and Trade Regulation Reporter, as well as from information obtained directly from the DOJ and the FTC. From this population, we excluded firms with investigations spanning less than one year, firms not operating in the mining or manufacturing industries (i.e., not operating in the 1000 to 3999 SIC code range), and firms not settling their cases with the
(Eckbo and Wier, 1985; Wier, 1983). ${ }^{7}$ Thus, by sampling settling firms, we increase the likelihood of including only firms with significant earnings management incentives.

In addition to the experimental sample of investigated firms, two control samples were selected from the Manufacturing Sector Master File developed by Hall (1989). This file contains approximately 2700 Compustat manufacturing firms. ${ }^{8}$ One control sample was randomly selected, while the second was matched to investigated firms' size based on total assets. These control samples of noninvestigated firms are used to isolate factors other than the phenomenon of interest. For example, previous research

Table 1. Experimental Sample Selection: 1974 - 1992

Total number of investigated firms on Compustat data tapes Total

Firms whose investigations spanned less than one year

Firms operating outside the sample industries

Firms not settling with FTC or DOJ

Number of firms in final sample

DOJ and the FTC. Firms not operating in the sample SIC code range were excluded to control for industry-specific characteristics. ${ }^{4}$ As detailed in Table 1, these screens resulted in an experimental sample of 86 investigated firms. ${ }^{5}$

Section 7 investigations ultimately are either settled or litigated to conclusion. We excluded firms not settling their cases with antitrust regulators to control for differences in earnings management incentives across investigation outcomes. Prior studies provide evidence that firms under investigation for Section 7 violations face substantial opportunity costs in delaying the merger, and thus agree to settle their case on the regulator's terms, regardless of the underlying legal merits of such terms (see Coate, Kleit, and Bustamante, 1995) ${ }^{6}$ Moreover, case settlements usually involve divestitures that impose significant economic constraints on settling firms suggests that large firms are more politically sensitive, and thus are more likely to manage their reported earnings downward (see Watts and Zimmerman, 1986).

Table 2 provides descriptive statistics on total accrual changes, earnings changes, cash flow changes, and revenue changes for the experimental sample firms. ${ }^{9}$ These statistics are for the year the investigation ended (year 0), as well as for the investigation year preceding the end of the investigation (year -1) and the year following the end of the initial investigation (year +1 ). Panel A of Table 2 shows that total accrual changes are negative and significant (using parametric statistical tests) in year +1 only. Previous studies have used accrual changes as a measure of discretionary accruals (see, e.g., DeAngelo, 1986). ${ }^{10}$ Thus, there is some evidence that investigated firms managed earnings re- 
Panel A: Total accrual changes ${ }^{\mathrm{a}}$

\begin{tabular}{|c|c|c|c|}
\hline Mean & .0041 & -.0096 & -.0222 \\
\hline Median & -.0119 & -.0027 & -.0090 \\
\hline $\mathrm{n}$ & 43 & 70 & 68 \\
\hline Percent positive & $44.19 \%$ & $42.86 \%$ & $44.12 \%$ \\
\hline Parametric $p$-value ${ }^{\mathrm{b}}$ & .8789 & .5065 & .0314 \\
\hline Nonparametric $p$-value ${ }^{\mathrm{b}}$ & .1862 & .5573 & .1387 \\
\hline \multicolumn{4}{|c|}{ Panel B: Earnings changes ${ }^{\mathrm{a}}$} \\
\hline Mean & -.0292 & -.0044 & .0133 \\
\hline Median & .0089 & .0055 & .0108 \\
\hline $\mathrm{n}$ & 46 & 78 & 81 \\
\hline Percent positive & $80.43 \%$ & $60.26 \%$ & $69.14 \%$ \\
\hline Parametric $p$-value ${ }^{\mathrm{b}}$ & .5351 & .6614 & .0031 \\
\hline Nonparametric $p$-value ${ }^{\mathrm{b}}$ & .0002 & .1568 & .0002 \\
\hline \multicolumn{4}{|c|}{ Panel C: Cash flow changes ${ }^{\mathrm{a}}$} \\
\hline Mean & -.0010 & -.0161 & .0051 \\
\hline Median & .0102 & .0043 & .0184 \\
\hline $\mathrm{n}$ & 39 & 67 & 66 \\
\hline Percent positive & $56.41 \%$ & $53.73 \%$ & $63.64 \%$ \\
\hline Parametric $p$-value $^{\mathrm{b}}$ & .9631 & .7418 & .8200 \\
\hline Nonparametric $p$-value ${ }^{\mathrm{b}}$ & .6511 & .9066 & .0409 \\
\hline \multicolumn{4}{|c|}{ Panel D: Revenue changes ${ }^{\mathrm{a}}$} \\
\hline Mean & .1236 & .0574 & .1462 \\
\hline Median & .1261 & .0819 & .1191 \\
\hline $\mathrm{n}$ & 49 & 80 & 83 \\
\hline Percent positive & $85.71 \%$ & $72.50 \%$ & $87.95 \%$ \\
\hline Parametric $p$-value ${ }^{\mathrm{b}}$ & .0001 & .0410 & .0001 \\
\hline Nonparametric $p$-value ${ }^{\mathrm{b}}$ & .0001 & .0001 & .0001 \\
\hline
\end{tabular}

${ }^{a}$ Total accruals are defined to include the changes in accounts receivable, inventory, accounts payable, and income tax payable less depreciation and amortization expense and deferred tax expense, and are scaled by total assets. Earnings are defined as income before extraordinary items, and are scaled by total assets. Cash flows are defined to include earnings, depreciation, deferred taxes, and the changes in accounts receivable, inventory, accounts payable, and income tax payable, and are scaled by total assets. Revenues are defined as net sales, and are scaled by total assets. The number of firms is given by $n$.

${ }^{b}$ The parametric $p$-value is for a two-sided $t$-test, where year $0(-1)$ is the year at (prior to) the end of the investigation and year +1 is the year following the initial investigation. The nonparametric $p$-value is for a twosided Wilcoxon test.

ported in the year following their case settlement.

Panel B of Table 2 shows that earnings changes also are significant for both year +1 (using both parametric and nonparametric statis- tical tests) and year -1 (using nonparametric statistical tests). Such evidence suggests that the year +1 results in Panel A perhaps were driven by firm-specific economic circumstances. ${ }^{11}$ This interpretation is reinforced by the results reported in Panels C and D of Table 2 for cash 
flow changes and revenue changes, respectively. In sum, the descriptive evidence detailed in Table 2 gives us reason to believe that the year +1 results may contain an element of earnings management (i.e., discretionary accruals), in addition to changes caused by economic circumstances (i.e., nondiscretionary accruals).

With regard to the earnings management incentives associated with the year +1 evidence, our sample of settling firms is dominated by divestitures ( 70 of the 86 total sample firms). Divestiture settlements involve substantial economic constraints that extend beyond the investigation period (see, e.g., Eckbo and Wier, 1985). ${ }^{12}$ Antitrust observers note that firms agree to such costly settlements in order to expedite the merger. Coate, Klein, and Bustamante (1995), for example, observed that firms agree to dispose of contested assets in order to avoid opportunity costs of further merger delay, and then deal with the alleged violation later. Thus, settling firms have incentives to manage earnings reported in periods after the initial settlement. In dealing with their alleged antitrust violations, firms may introduce income-decreasing accruals to ease the severity of the initial violation and/or as evidence of economic hardship attributable to the initial outcome. ${ }^{13}$ These efforts to influence regulators' discernment of anticompetitive behavior also help minimize any ex-post settling up by the regulators and/or the courts relative to the initial investigation outcome. ${ }^{14}$ In contrast to such post-investigation outcome incentives, reducing earnings reported prior to the initial investigation actually may work against a firm's efforts to expedite the merger. For example, income-decreasing manipulations would hinder the firm's ability to secure merger financing.

\section{Hypothesis Testing and Results}

While the descriptive results in Table 2 provide some evidence of earnings management (discretionary accruals), the results also suggest the presence of nondiscretionary accruals. To test the hypothesis that investigated firms' dis- cretionary accruals are significantly income decreasing in periods surrounding the investigation, we model the nondiscretionary component of accruals. Specifically, we use the following OLS regression model:

$\mathrm{TAA}_{\mathrm{it}}=\mathrm{i}+\beta_{1 \mathrm{i}}$ ChgREVA $_{\mathrm{it}}+\beta_{2 \mathrm{i}}$ PPEA $_{\mathrm{it}}+\mathrm{it}$ (1)

where TAAit is the total accruals deflated by total assets in year $t$ for investigated firm $i$; ChgRE$V A_{i t}$ is the revenues in year $t$ less revenues in year $t-1$ for investigated firm $i$, deflated by total assets in year $t$ for investigated firm $i$; and PPEA it is the gross property, plant, and equipment deflated by total assets in year $t$ for investigated firm $i$.

Equation (1) is based on Jones (1991), where the nondiscretionary component represents what accruals would have been in the absence of manipulation. Similar to Defond and Jiambalvo (1994), we use equation (1) to analyze the nondiscretionary component of both total accruals and working capital accruals. Total accruals are defined as changes in specific working capital accounts (i.e., accounts receivable, inventory, accounts payable, and income taxes payable) less the current period's depreciation and deferred tax expense (see, e.g., Healy, 1985). Working capital or current accruals, which are considered more susceptible to manipulation, exclude the adjustment for depreciation, amortization, and deferred taxes (see DeFond and Jiambalvo, 1994).

The change in revenues variable (ChgREVA) controls for economic events likely to influence noncash working capital, while the gross property, plant, and equipment variable (PPEA) captures the effect of nondiscretionary depreciation and deferred taxes. ${ }^{15}$ Discretionary accruals are proxied using prediction errors (uip) based on coefficients from nonevent-period pooled estimates of equation (1):

uip $=$ TAA $_{i p}-\left(a+b_{1}\right.$ ChgREVAip $+b_{2}$ PPEA $\left._{\text {ip }}\right)$

where $\mathrm{p}$ is a year index for years included in the 
prediction period. Nondiscretionary accruals are represented by the term in parenthesis. Thus, equation (2) calculates the difference between actual accruals (TAA) and an estimate of what accruals should be in the absence of earnings management (i.e., nondiscretionary accruals).

Panels A and B of Table 3 provide the results of hypothesis tests using equation (2) prediction errors in year +1 , calculated for total accruals and current accruals, respectively. Results in both year -1 and year 0 generally are insig- nificant and therefore are not presented. The year +1 results are robust to sensitivity tests. ${ }^{16}$ As discussed in relation to Table 2 above, investigated firms' earnings management incentives relate to their efforts to expedite a merger. In contrast, income-decreasing accruals prior to the initial case outcome may hinder efforts to consummate the merger. As in Table 2, both parametric $t$-test results and nonparametric Wilcoxon test results are provided for the experimental sample. In addition, control group results are detailed.

Table 3. Experimental and Control Sample Tests of Hypothesis

Using Prediction Errors in Year +1

\section{Experimental \\ Sample}

\author{
Randomly-selected \\ Control Sample
}

Size-matched Control Sample

Panel A: Total accruals ${ }^{\mathrm{a}}$

Mean

$-.0158$

$-.0123$

.0548

Std. deviation

n

Parametric $p$-value ${ }^{\mathrm{b}}$

74

.0078

Nonparametric $p$-value ${ }^{\mathrm{b}}$

.0119

-.0061
.0038
.0903
83
.2696
.3781

$-.0021$

$-.0006$

.0499

81

.3544

.4324

Panel B: Current accruals ${ }^{\mathrm{a}}$

Mean

$-.0140$

$-.0113$

.0508

Std. deviation

74

.0100

Parametric $p$-value ${ }^{\mathrm{b}}$

.0099

$-.0006$

$-.0003$

.0422

81

.4472

.3979

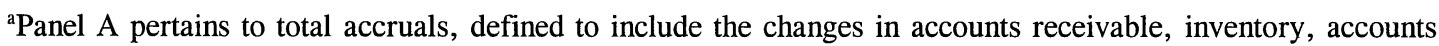
payable, and income tax payable less depreciation and amortization expense and deferred tax expense, and are scaled by total assets. Panel B pertains to current or working capital accruals, defined to include the changes in accounts receivable, inventory, accounts payable and income tax payable. The number of firms is represented by $\mathrm{n}$. Prediction errors are calculated using ordinary least squares estimated coefficients from the following equation:

TAA $_{i t}=\alpha_{i}+\beta_{1 i}$ ChgREVA $_{i t}+\beta_{2 i}$ PPEA $_{i t}+\varepsilon_{i t}$

where TAA it is the total accruals deflated by total assets in year $t$ for investigated firm $i$; ChgREVAit is the revenues in year $t$ less revenues in year $t-1$ for investigated firm $i$, deflated by total assets in year $t$ for investigated firm $i$; and PPEA it is the gross property, plant, and equipment deflated by total assets in year $t$ for investigated firm $i$.

${ }^{\mathrm{b}}$ All $p$-values are one-sided tests, using either the parametric $t$-test or the nonparametric Wilcoxon test. 
Referring to Panel A, the experimental sample prediction errors are negative and significant for both the mean (parametric $t$-test) and median (nonparametric Wilcoxon test) discretionary accruals. Likewise, the mean and median prediction errors for working capital accruals in Panel B are negative and significant. Consistent with our hypothesis, the negative and significant prediction errors indicate that investigated firms' discretionary accruals were income decreasing. In contrast, the control group results are not significant, also consistent with expectations.

\section{Summary and Conclusions}

This study considers whether reported earnings information is manipulated by firms investigated for antitrust merger violations by the Department of Justice and the Federal Trade Commission. We expected that investigated firms would choose income-decreasing accounting accruals to avoid the appearance of excess profits and anticompetitive behavior. Both the descriptive and inferential analyses provide evidence that is consistent with our hypothesis that investigated firms' discretionary accruals are significantly income decreasing in periods surrounding the antitrust merger investigation.

Our evidence of earnings management supports Bruns and Merchant's (1990) belief that "anyone who uses information on short-term earnings is vulnerable to misinterpretation, manipulation, or deliberate deception" (p. 22). Regardless of whether such earnings management efforts are within or outside the bounds of GAAP, the quality of reported earnings suffers. The evidence is also in agreement with previous studies (e.g., Jones, 1991; Cahan, 1992) that report that firms have incentives to reduce earnings in order to influence regulatory efforts. Our results indicate that firms investigated under Section 7 of the Clayton Act do manage reported earnings. Thus, antitrust regulators need to be wary of investigated firms' reported accounting information. The manipulation of earnings information used in antitrust merger investigations complicates the already difficult task of identifying and prohibiting anticompetitive behavior. By documenting earnings management practices of investigated firms, this study may prove helpful in understanding the apparent ineffectiveness of governmental antitrust merger policy.

\section{Suggestions for Future Research}

This study contributes to the earnings management literature by exploring the context of antitrust merger investigations and by considering the implications of such manipulations for reported earnings quality. Thus, the study responds to calls for research on the usefulness or quality of reported earnings in general, and accounting accruals in particular. Considering the importance of such information to the external reporting process, there is great need for additional research on accruals and earnings quality in other settings. For example, future studies could consider settings where earnings management incentives other than political costs are prevalent (e.g., compensation contracts, debt covenants), as well as other political cost settings.

\section{Endnotes}

1. In contrast to the accounting choice analysis in political cost studies, researchers have used stock prices to examine the earnings management incentives pertaining to income smoothing (see, e.g., Wang and Williams, 1994). For a summary and critique of both types of earnings management studies, see Ronen and Sadan (1981) and Watts and Zimmerman (1990).

2. In Section 7 investigations, the DOJ considers the financial condition of a merging firm as well as any other firm in the relevant market (United States Department of Justice, 1984).

3. Previous studies support the use of profits in discerning a merger's competitive effect with reference to empirical evidence of a positive correlation between market con- 
centration and profits (see, e.g., Weiss, 1974). As a recent example, the 1996 proposed merger of PacifiCare and FHP International has raised concerns that the resulting increased concentration would allow the combined firm to increase profits without any fear of competition (Gruely and Rundle, 1996).

4. Excluding firms operating in the nonmining or nonmanufacturing industries (i.e., outside the 1000 to 3999 SIC code range) helps control for industry specific characteristics. For example, prior studies note the unique earnings management incentives facing financial institutions (see Moyer, 1990).

5. Due to data requirements, the number of firms used in subsequent analysis ranges from 39 to 83 firms. The most pervasive causes for reductions in the number of 1974-1992 sample observations were the use of lagged values in calculating first differences (e.g., in calculating total accruals for 1974 , data from 1973 is required), the short duration of Section 7 cases ending in settlement, and the absence of post-merger data for firms that were acquired. We also excluded several observations deemed to be outliers with fundamentally different economic circumstances, in order to obtain reliable statistical conclusions.

6. As Kleit (1997) observes "It is unsurprising that firms are often willing to strike any kind of deal, just to get the government out of the way of their mergers" (p. A18). In response to complaints of costly regulatory delays in merger investigations, the FTC has recently adopted rules designed to provide faster and cheaper decisions. Under this "fast track" option, merging companies can expect a final decision within 13 months (Gruely, 1996).

7. In contrast to case settlement outcomes, the evidence regarding the costs imposed on litigating firms is mixed (see Wier, 1983). Consistent with previous studies, our sample of settling firms is dominated by divestitures (70 of the 86 sample firms).

8. Hall (1989) created the Manufacturing Sector Master File at the National Bureau of Economic Research. A special feature of the data file is the inclusion of approximately 1200 firms that exited Compustat due to mergers and other changes in corporate form.

9. The mean number of firms used in calculations varies from 44 in year -1 to 74 in year +1 . The fewer number of observations in the investigation year prior to the end of the investigation (i.e., in year -1) reflects the short duration of Section 7 investigations that end in settlement. In addition, the number of firms used in all three-event periods is reduced by the absence of post-merger data and the use of lagged values in calculating first differences. This latter factor is especially constraining on total accruals and cash flows variables, as these variables in any one year (i.e., before calculating the change across years) include the change in various accounts (e.g., both variables include the change in accounts receivable).

10. Dechow, Sloan, and Sweeney (1995) note that the use of accrual changes as a discretionary accruals measure is appropriate if the nondiscretionary accrual component follows a random walk.

11. Previous studies caution that accrual changes may reflect changes in a firm's economic circumstances. Kaplan (1985), for example, argues that total accruals may decrease when demand declines, as fewer receivables are needed to support sales levels. Thus, accrual changes may be due in part to nondiscretionary accruals, as opposed to discretionary accruals.

12. While costly, divestitures often are delayed for years after the settlement date, allowing defendants "ample time during which to collect their alleged monopoly profits" (Wier, 1983, p. 208). Consistent 
with such delays, the experimental sample's mean total assets are not statistically different ( $t$-value $=.285$ ) between the year following the initial investigation and all other years. This suggests that our sample firms do not undertake divestitures until sometime after year +1 .

13. See Hall and Stammerjohan (1996) for additional discussion of using a defendant's financial condition as evidence of economic hardship in appeals of initial damage awards. With regard to postmerger appeals of initial investigation outcomes, Johnson and Parkman (1991) note that antitrust authorities place significant importance on post-acquisition evidence of anticompetitive behavior.

14. Ex-post settling up by the regulators and/or the courts can arise from the review of antitrust case settlements under the Tunney Act. During or after this postinvestigation period of review, the courts may reject a settlement that does not reasonably advance the public's interests.

15. Similar to DeFond and Jiambalvo (1994), we exclude the property, plant, and equipment variable from both equations (1) and (2) for working capital analyses because neither depreciation nor deferred taxes are included in such current accruals. Other than this exclusion, analyses of working capital accruals and total accruals are identical.

16. We follow Dechow, Sloan, and Sweeney (1995) in examining the sensitivity of Table 3 results to revenue manipulations and extreme financial performance. In the first case, the modified Jones model prediction errors for both total accruals and current accruals remain statistically significant (at a .05 level). Similarly, we use earnings and cash flow measures to evaluate the potential misspecification associated with extreme financial performance. Neither variable is statistically different (at a .05 level) across the experimental and control groups. Thus, our experimental sample is not different from either control group in terms of financial performance. For additional discussion of extreme financial performance and earnings management, see Beneish (1997).

\section{References}

1. Areeda, P., Antitrust Analysis: Problems, Text, Cases, Boston: Little, Brown and Company, 1988.

2. Baker, J. B. and T. F. Bresnahan, "Empirical Methods of Identifying and Measuring Market Power," Antitrust Law Journal, Vol. 61, No. 1, pp. 3-16, 1992.

3. Beneish, M. D., "Detecting GAAP Violations: Implications for Assessing Earnings Management among Firms with Extreme Financial Performance," The Journal of Accounting and Public Policy, Vol. 16, No. 3, pp. 271-309, 1997.

4. Bruns, W. J. and K. A. Merchant, "The Dangerous Morality of Managing Earnings," Management Accounting, Vol. 72, No. 2, pp. 22-25, 1990.

5. Cahan, S. F., "The Effect of Antitrust Investigations on Discretionary Accruals: A Refined Test of the Political-Cost Hypothesis," The Accounting Review, Vol. 67, No. 1, pp. 77-95, 1992.

6. Coate, M. B., A. N. Kleit, and R. Bustamante, "Fight, Fold or Settle? Modeling the Reaction to FTC Merger Challenges," Economic Inquiry, Vol. 33, pp. 537-551, 1995.

7. DeAngelo, L. E., “Accounting Numbers as Market Valuation Substitutes: A Study of Management Buyouts of Public Shareholders," The Accounting Review, Vol. 61, No. 3, pp. 400-420, 1986.

8. Dechow, P., R. Sloan, and A. Sweeney, "Detecting Earnings Management," The Accounting Review, Vol. 70, No. 2, pp. 193-225, 1995.

9. DeFond, M. L. and J. Jiambalvo, "Debt Covenant Violation and Manipulation of Accruals," Journal of Accounting and 
Economics, Vol. 17, No. 1, pp. 145-176, 1994.

10. Easterwood, C. M., "Takeovers and Incentives for Earnings Management: An Empirical Analysis," Journal of Applied Business Research, Vol. 14, No. 1, pp. 29-47, 1998.

11. Eckbo, B. E., "Mergers and the Value of Antitrust Deterrence," The Journal of Finance, Vol. 47, No. 3, pp. 1005-1029, 1992.

12. Eckbo, B. E. and P. Wier, "Antimerger Policy under the Hart-Scott-Rodino Act: A Reexamination of the Market Power Hypothesis," Journal of Law and Economics, Vol. 28, No. 1, pp. 119-149, 1985.

13. Eisner, M. A. and K. J. Meier, "Presidential Control Versus Bureaucratic Power: Explaining the Reagan Revolution in Antitrust," American Journal of Political Science, Vol. 34, No. 1, pp. 269-287, 1990.

14. Elzinga, K. G., "Unmasking Monopoly: Four Types of Economic Evidence," in R.J. Larner and J.W. Meehan, Jr. (eds.) Economics and Antitrust Policy, Westport, Connecticut: Quorum Books, pp. 151177, 1989.

15. Financial Accounting Standards Board, Objectives of Financial Reporting by Business Enterprises, Norwalk, Connecticut: Author, 1978.

16. Financial Accounting Standards Board, Qualitative Characteristics of Accounting Information, Norwalk, Connecticut: Author, 1980.

17. Frank, S. E. and E. S. Browning, "Citicorp Net: Special Items Aided Results," The Wall Street Journal, Jan. 28, pp. C1C2, 1998.

18. Gruely, B., "FTC, Heeding Companies' Complaints, Moves to Speed Its Challenges to Mergers," The Wall Street Journal, Sept. 18, p. A3, 1996.

19. Gruely, B. and R. L. Rundle, "FTC Looks Hard at PacifiCare's Plan to Buy
FHP," The Wall Street Journal, Oct. 10, p. A3, 1996.

20. Hall, B. H., The Manufacturing Sector Master File: Documentation, Stanford: National Bureau of Economic Research, 1989.

21. Hall, S. C., and W. W. Stammerjohan, "Damage Awards and Earnings Management in the Oil Industry," The Accounting Review, Vol. 72, No. 1, pp. 47-65, 1996.

22. Healy, P. M., "The Effect of Bonus Schemes on Accounting Decisions," Journal of Accounting and Economics, Vol. 7, No. 1, pp. 85-107, 1985.

23. Ip, G. "Write-Offs May Become WriteOns," The Wall Street Journal, Dec. 30, pp. C1-C2, 1996.

24. Johnson, R. N. and A. M. Parkman, "Premerger Notification and the Incentive to Merge and Litigate," Journal of Law, Economics and Organizations, Vol. 7, No. 1, pp. 145-162, 1991.

25. Jones, J. J., "Earnings Management During Import Relief Investigations," Journal of Accounting Research, Vol. 29, No. 2, pp. 193-228, 1991.

26. Kaplan, R. S., "Comments on Paul Healy: Evidence on the Effect of Bonus Schemes on Accounting Procedures and Accrual Decisions," Journal of Accounting and Economics, Vol. 7, No. 1, pp. 109-113, 1985.

27. Kleit, A. "How to Streamline Antitrust," The Wall Street Journal, Mar. 4, p. A18, 1997.

28. Lev, B. "Usefulness of Earnings Research," Journal of Accounting Research, Vol. 27, Supplement, pp. 153-201, 1989.

29. Lowenstein, R., "Antitrust Enforcers Drop the Idealogy, Focus on Economics," The Wall Street Journal, Feb. 27, p. A1, 1997.

30. Makar, S., P. Alam, and M. Pearson, "Earnings Management: The Case of Political Costs Over Business Cycles," Business \& Professional Ethics Journal, Vol. 15, No. 2, pp. 33-50, 1996. 
31. Moyer, S. E., "Capital Adequacy Ratio Regulations and Accounting Choices in Commercial Banks," Journal of Accounting and Economics, Vol. 13, No. 2, pp. 123-154, 1990.

32. Murray, A., "Merger Wave May Put Spotlight on Antitrust," The Wall Street Journal, Apr. 8, p. A1, 1996.

33. Novak, V., D. Clark, and S. K. Yoder, "Judge Rejects Agreement between U.S. and Microsoft," The Wall Street Journal, Feb. 15, p. A1, 1995.

34. Ronen, J. and S. Sadan, Smoothing Income Numbers: Objective, Measures and Implications, Reading, Massachusetts: Addison-Wesley, 1981.

35. Schipper, K., "Earnings Management," Accounting Horizons, Vol. 3, No. 4, pp. 91-102, 1989.

36. United States Department of Justice, Merger Guidelines, Washington, D.C.: Author, 1984.

37. Waldman, D.E., Economics of Antitrust: Cases and Analysis, Boston: Little, Brown and Company, 1986.

38. Wang, Z. and T. H. Williams, "Accounting Income Smoothing and Stockholder Wealth," Journal of Applied Business Research, Vol. 10, No. 3, pp. 96104, 1994.

39. Waters, T. J., "Antitrust Law and Policy: Rule of Law or Economic Assumptions?" in R. J. Larner and J. W. Meehan, Jr. (eds.) Economics and Antitrust Policy, Westport, Connecticut: Quorum Books, pp. 151-177, 1989.

40. Watts, R. L. and J. L. Zimmerman, Positive Accounting Theory, New Jersey: Prentice Hall, 1986.

41. Watts, R. L. and J. L. Zimmerman, "Positive Accounting Theory: A Ten Year Perspective," The Accounting Review, Vol. 65, No. 1, pp. 131-155, 1990.

42. Weiss, L. W., "The Concentration-Profit Relationship and Antitrust," in H. J. Goldschmid, H. M. Mann, \& J. F. Weston (eds.) Industrial Concentration: The
New Learning, Boston: Little, Brown and Company, pp.184-233, 1974.

43. Wier, P., "The Costs of Antimerger Lawsuits," Journal of Financial Economics, Vol. 11, No. 1, pp. 207-226, 1983. 